\title{
EM GUARDA! O ESPECTRO DO COMUNISMO RONDA A CASERNA: A CONSTRUÇÃO MILITAR DA IMAGEM OBSCENA DO COMUNISMO NO ESTADO NOVO
}

\author{
ON GUARD! THE ESPECTRE OF COMMUNISM IS \\ HAUNTING BARRACK: THE CONSTRUCTION OF \\ MILITARY IMAGE OBSCENE FROM COMMUNISM IN \\ NEW STATE
}

Ronaldo Queiroz Morais*

\begin{abstract}
Resumo: A proposição desse artigo é a de historiar a construção militar da imagem obscena do comunismo como monumento de poder; em contexto social e político de medo e ojeriza às ideias de esquerda, por parte das elites conservadoras, e de consolidação do Exército brasileiro como instituição moderna. Sendo assim, os documentos que revelam o anticomunismo militar não se apresentam apenas como reflexo da mistificação e do medo da esquerda política, mas - sobretudo - são representativos da construção de práticas normativas de estruturação da própria identidade do corpo militar e do Exército. Portanto, a transformação do corpo comunista em monstro, não é mera banalização política da alteridade, na medida em que o processo de monstrualização da esquerda política teve uma relação importante com a emergência da instituição militar como ator político e internamente favoreceu uma coesão sem precedentes na caserna.
\end{abstract}

Palavras-chave: Exército. Anticomunismo. Coesão Militar.

\footnotetext{
* Professor convidado no Programa de Pós-Graduação em História da Faculdade PortoAlegrense (FAPA) e professor do Colégio Militar de Porto Alegre (CMPA). E-mail: ronaldoqueirozster@gmail.com
} 


\begin{abstract}
The proposition of this article is to historicize the military image construction obscene from communism as monument of power; in a social and political context of fear and aversion of the left ideas on the part of conservative elites and of consolidation of Brazilian Army as modern institution. Thus, the documents reveal that the military anticommunism it is not only a reflection of the fear and mystification of the political left, but - above all - it is representative of the construction of normative practices structuring of the of own identity military corporation. Therefore, the transformation of the communist body into political monster, is not a mere trivialization of otherness, to the extent that the process monstrualização of the political left had an important relationship with the emergence of the institution military as a political actor and internally promoted an unprecedented cohesion in the barracks.
\end{abstract}

Keywords: Army. Anticommunism. Military Cohesion.

[...] Ora, curiosamente, e de uma maneira que me parece bastante característica, o primeiro monstro moral que aparece é o monstro político.

Michel Foucault

Representar uma cultura prévia como monstruosa justifica seu deslocamento ou extermínio, fazendo com que o ato de extermínio apareça como heroico.

Jeffrey Jerome Cohen

Criou-se o estereótipo de que contra comunistas, e no conceito eram abrangidos todos os que defendiam interesses nacionais e os princípios democráticos, tudo era válido: tratava-se não de gente, de criaturas humanas, mas de animais perigosos, contra os quais todos os processos eram lícitos.

Nelson Werneck Sodré

\title{
INTRODUÇÃO
}

O anticomunismo foi, de fato, uma reação ao iminente "perigo vermelho". Num período histórico de intensa polarização político-ideológica, proporcionou efeitos, segundo um moderado diplomata britânico, de uma verdadeira guerra religiosa, típica do século XVI. ${ }^{1} \mathrm{O}$ mundo moderno burguês parecia estar em perigo, as forças comunistas anunciavam que a revolução era uma questão de tempo. A cada avanço político do comunismo desencadeavase, potencialmente, a reação conservadora da ordem cristã e do mercado livre. Na conjuntura moderna de horror e de medo as representações políticas 
do comunismo, grosso modo, inclinavam-se na direção da banalização dos corpos dissidentes. Essa banalização, objetivamente, monstrualizou a esquerda política, em poucas palavras, qualificou estes corpos como seres monstruosos. Estamos, objetivamente, diante do monstro político indicado por Michel Foucault, estratégia moderna de uma nova tecnologia de poder que, longe da mera banalização, impõe mecanismos permanentes de vigilância e de controle, construindo um monstro moral que ameaça o rompimento com o pacto social capitalista. $^{2}$

Dos efeitos de poder referentes ao anticomunismo militar o mais imediato foi, sem dúvida, o da banalização dos corpos de esquerda. A fonte de toda a banalização militar concentrou-se na comemoração de 27 de novembro, na chamada "Revolução Comunista de 1935", que amiúde foi ressignificada para atender às necessidades do presente, pontuou todo um imaginário de repulsa ao comunismo. ${ }^{3}$ A normalização político-militar do evento proporcionou a coesão institucional que garantiu o esmagamento, paulatino, dos corpos desviantes no meio militar. De forma que o anticomunismo militar passou a sensibilizar o corpo institucional, favorecendo a ação corporativa em defesa da própria existência do Exército como organização moderna. A ameaça comunista a partir do Estado Novo foi posta pela instituição como um perigo real, que, essencialmente, ameaçava a caserna com a infiltração de agentes perniciosos.

Com relação ao "perigo vermelho" é preciso tecer algumas considerações: primeiramente, em termos concretos o comunismo no Brasil, como era apresentado pelos anticomunistas, se encaixaria numa longa história do medo que as elites tinham das forças populares, nada mais do que isto. No entanto, após a sublevação político-militar de 1935, o comunismo apresentavase para os anticomunistas e comunistas como uma possibilidade realmente existente de estabelecer-se no país. Nesse sentido, o comunismo encontrava-se dentro de um universo de possibilidades concretas. Assim, o "perigo vermelho" pôs, objetivamente, os militares "em guarda" contra toda possibilidade de comunização do Brasil. Além disso, o anticomunismo militar atuou como instrumento político-militar de coesão institucional e de barganha política de intervenção sobre o próprio Estado. Para isso, foi fundamental a transformação do comunismo em potencial inimigo militar, utilizando-se das representações anticomunistas já existentes no meio civil. Certamente, o anticomunismo militar só foi possível num contexto geral, absolutamente favorável - momento de tensão social, em que o medo do "perigo vermelho" empolgava a sociedade como um todo. O general Newton de Andrade Cavalcante, em setembro de 1937, representando a instituição, traduz a mentalidade conservadora frente a este perigo: "Não existiu e nem existe em todo o curso da nossa História e creio, mesmo, que da Universal, um período tão cheio de apreensões e perigos e tão pontilhado de indecisões como o que estamos vivendo". ${ }^{4} \mathrm{O}$ medo da ameaça comunista agenciou a opinião pública, inclusive a militar, no sentido de relativizar a liberdade política moderna. 


\section{A BANALIZAÇÃO DOS CORPOS MILITARES DE ESQUERDA}

A banalização dos corpos militares dissidentes, dos oficiais subalternos que participaram da sublevação de novembro de 1935, teve presença importante na economia dos discursos e das imagens de verdade apresentados nos documentos militares a partir do Estado Novo. Naturalmente, estes corpos foram banalizados, na medida em que a fonte do anticomunismo encontrava-se naquela sublevação. De forma que a banalização da esquerda política apresentou o militar de esquerda a partir de uma imagem obscena. Um verdadeiro monstro político. O comunismo no meio militar passou a ser incompatível com a condição de profissional das armas, de acordo com o Ministro da Guerra, general Eurico Gaspar Dutra: “[...] aquele que o pratica ou dele se mostra adepto, oficial ou soldado, enxovalha a farda que veste, é indigno de ostentar o uniforme e conduzir as armas que a Nação lhe confiou [...]". ${ }^{5}$ Houve de fato uma marcação territorial, a construção de um espaço em que o comunismo ou qualquer noção correlata, apresentava-se como um câncer, doença maligna, que levava qualquer corpo à morte.

Assim, o anticomunismo militar postou-se como elemento vital ao corpo institucional, pois assegurava a formação de anticorpos para a proteção da instituição. Nessa visão, a corporação deveria constituir uma linha de defesa e expelir do Exército todo o corpo estranho - o corpo dissidente, o anormal. Nesse sentido, foi fundamental a banalização de todo o corpo dissidente, tendo como ponto de partida a transformação dos militares de esquerda de $1935 \mathrm{em}$ monstros políticos - corpos indignos, traidores em potencial -, deslocados de qualquer noção de camaradagem militar. Em suma, o primeiro monstro político significativo no Exército foi o monstro militar de esquerda, aquele que através da "Intentona Comunista de 35", ou melhor, de um "intento louco" - um motim militar - ameaçou a ordem na caserna investindo contra a hierarquia e a disciplina. Obviamente, não foi o primeiro caso na instituição; no entanto o evento foi elaborado ideologicamente a fim de produzir na tropa um sentido monstruoso. Dessa forma, a traição aos irmãos de arma, o ataque na escuridão da noite, a perfídia da ação, foram práticas acentuadas nos discursos militares - elementos importantes para a construção da imagem do monstro militar de esquerda. Naturalmente, a camaradagem é inalienável ao militar; portanto a quebra desse valor representa um ato torpe, infame e obsceno, em outras palavras, só um monstro seria capaz de cometer tal quebra de valor moral militar.

É evidente, no anticomunismo, a banalização da esquerda e de seus seguidores. Entre os militares não foi diferente; porém não podemos reduzir o anticomunismo militar à mera banalização dos corpos dissidentes, pois a banalização remete-nos às relações de poder que por meio institucional asseguraram mudanças importantes no Exército brasileiro. Dito de outro 
modo, a banalização dos corpos apresenta-se como indício de práticas de poder no interior dos quartéis. E essas práticas apontam na direção de uma cultura político-militar que por meio da banalização dos corpos desviantes viabilizou a existência de uma instituição militar capaz de colocar-se como vanguarda da ordem e do progresso nacional. Destarte, o anticomunismo militar não pode ser reduzido à simples banalização de tudo o que se refere ao comunismo, na medida em que ele carrega elementos normalizantes, fundamentais, para a compreensão da organização do Exército como instituição e como ator político a partir do Estado Novo.

No contexto da banalização ordinária dos corpos militares de esquerda, a monstrualização como representação política foi recorrente. O sentido monstruoso do comunismo era o que sintetizava toda a rejeição institucional. Nada singular ao Exército, a monstrualização do comunismo estava presente, também, nos discursos civis. Ademais, a monstrualização do "outro" que ameaça a ordem identitária não é um tema novo na história. A História Medieval está carregada de momentos de monstrualização da alteridade ameaçadora; os muçulmanos foram, amiúde, transformados em caricaturas demoníacas na Europa. ${ }^{6}$ No entanto, a monstrualização moderna, a construção política do "anormal", apresenta-se como um fenômeno recente. A propósito disso Michel Foucault percebe, em seu trabalho de historiador, que esse fenômeno refere-se aos séculos nos quais os burgueses assumem posições privilegiadas de poder, nas chamadas Revoluções Burguesas - momento em que houve a transformação, primeiramente do rei em "monstro político" e depois dos trabalhadores em "monstro popular". ${ }^{7}$ Não convém discorrer sobre seus exemplos documentais e argumentos teóricos (que são muitos), mas o que chama atenção é a estratégia política burguesa que modernamente transforma tudo o que ameaça a ordem estabelecida, em "monstro". De todos os monstros modernos o "monstro político" é o mais perigoso; assim, o soberano despótico e o povo revoltado são as duas figuras anormais, monstruosas: o rei porque está acima das leis e o povo porque vive abaixo delas. Efetivamente, o criminoso monstruoso é aquele que rompe o pacto social e ameaça a ordem, enfim, aquele que visa à quebra da lei.

Nesse sentido, é que podemos atribuir o conceito de "monstro político" aos corpos dissidentes no interior da caserna, como também aos comunistas em geral. Trata-se de um olhar horizontal sobre as representações e as práticas de poder produzidas no interior da caserna. Com efeito, na visão conservadora militar, estes corpos não passavam de seres monstruosos que ameaçavam a existência da própria instituição. A história da monstrualização dos corpos dissidentes presente no projeto militar dominante, traduz uma cultura políticomilitar de inclinação conservadora, portanto anticomunista, que engendrou monstros numa teia de significados, amiúde ressignificada, que amarrava a todos. ${ }^{8}$ Assim, é preciso compreender esta cultura político-militar de tom 
anticomunista por meio dos monstros que ela gerou, pois o corpo monstruoso, segundo Jeffrey Jerome Cohen, é pura cultura. O corpo monstrualizado revela, de forma contundentemente literal, o medo, a ansiedade e a fantasia, o que lhes confere uma vida "anormal" e uma estranha independência frente à natureza humana. ${ }^{9}$

Ao final de 1937, nos primeiros momentos do Estado Novo no país, o anticomunismo militar fez-se presente num estrondo espetacularizado nas comemorações de 27 de novembro. Data, a partir de então, importante do calendário militar. Momento de conjunção de forças militares e civis contrárias à ideologia comunista. Nesta imensa caixa de pandora foram depositados todos os problemas políticos do Brasil e também os adversários do projeto conservador. Portanto, o anticomunismo não se reduziu, por parte dos conservadores, ao combate direto aos partidários ou simpatizantes do PCB, mas foi estrategicamente ressignificando todos os corpos dissidentes. Em dezembro de 1935, o coronel Benicio da Silva apresentou um discurso importante - mesmo não sendo o do Ministro da Guerra. Esse arrazoado, de certa forma, pontua os primeiros discursos anticomunistas incorporados à instituição. As palavras do coronel acentuam o iminente "perigo vermelho"; o movimento foi qualificado como o de infâmia contra o Exército e a Nação. A banalização dos corpos dissidentes confere a estes monstros uma posição abaixo do inimigo de guerra e um poder de sedução deslocado de qualquer moralidade humana. Estes monstros não se equiparam ao inimigo "normal" do outro lado da fronteira. Assim, conforme o coronel:

Disse agora certo deputado que estamos frente a um perigo igual ao perigo externo. Engana-se o ilustre parlamentar. Muito maior é a ameaça, pois o perigo externo não encerra no bojo a traição, não nos deixa ao alcance dos golpes dos companheiros de luta ou dos soldados que conduzimos ao combate. No perigo externo sabemos que à nossa frente está o inimigo e mesmo ao nosso lado ou em nossa tenda o estrangeiro, que pode ser o inimigo sempre, em qualquer parte, mas o inimigo leal, destemeroso, movido pelo patriotismo, mesmo quando espião. Mas no caso em apreço, os indivíduos, as massas que eles dirigem e que podem ser os falsos amigos que acolhemos à nossa mesa, as tropas que comandamos, não são inimigos caracterizados; são talvez traidores a quem confiamos e a quem nos entregamos com a mais absoluta confiança. ${ }^{10}$

Este pronunciamento do coronel Benício da Silva foi reaproveitado, num tempo em que este discurso na instituição assumia efeitos de verdade, na compilação de textos anticomunistas publicados pelo Estado-Maior do Exército 
em 1938. A organização do livro "Em Guarda! (Contra o Comunismo)" se deu em 1937, ano de intensa mobilização anticomunista no meio civil e militar. $\mathrm{O}$ anticomunismo, naquele momento, consistia na transformação da sublevação político-militar de esquerda de $1935 \mathrm{em}$ monumento de resistência ao comunismo. $\mathrm{O}$ evento foi representado numa intersecção de forças entre o campo religioso e o militar.

Em setembro foi organizada uma romaria cívica ao cemitério de São João Batista, em visita aos mortos de 27 de novembro de 1935, com o objetivo de deslocar para o presente a memória dos fatos ocorridos naquela ocasião. Desse modo, o evento na forma de monumento anticomunista nacional passou a representar a ojeriza conservadora amalgamando militares e civis. Em texto publicado no Jornal do Brasil, Porto da Silveira acrescenta que a romaria não deve ser composta apenas por militares, portanto não se trata de um movimento da classe militar, pois:

Não serão os militares que irão homenagear, num preito de saudade, outros militares mortos. É muito mais do que isso. É a Pátria inteira, por todas as suas classes, que irá ao Campo Santo dizer aos gloriosos mortos de Novembro que os bons cidadãos não lhes esquecem o sacrifício[.....$^{11}$

O Ministério da Guerra se fez presente à romaria cívica. No texto elaborado para a mobilização popular, descreve-se o contexto de novembro de 1935 marcado por dias de tragédia e vergonha, de ignomínia e traição, de desonra e ausência de patriotismo. Os militares de esquerda foram apresentados como um pequeno número de tresloucados, que ameaçaram as instituições brasileiras a serviço do comunismo internacional. ${ }^{12}$ No dia da romaria, 22 de setembro, o Ministério da Guerra enviou como representante o general Newton Cavalcante, notório anticomunista militar, para discursar em homenagem aos militares mortos em novembro de 1935. Por ordem do Ministro da Guerra esse discurso foi amplamente divulgado no Exército. É fundamental observar no documento as representações anticomunistas e o sentido que elas assumiram num contexto de construção do anticomunismo doutrinário militar. A partir de 1937 o comunismo foi caracterizado como perigo iminente de ameaça às conquistas da civilização cristã. Nesse período, de acordo com o general:

[...] presenciamos a aberração incrível dos homens negarem DEUS, traírem a PÁTRIA, assassinarem irmãos em benefício de uma tutela estranha e felaz, combater a FRATERNIDADE para se acumpliciarem, conscientes ou inconscientemente, com essa força apocalíptica que anseia pela realização de uma megalomaníaca loucura de absorção, de escravidão e de extermínio: o COMUNISMO selvagem e sanguinário. ${ }^{13}$ 
O sentido monstruoso do comunismo foi o que orientou praticamente todo o discurso do general Newton Cavalcante; aqueles corpos apartados da vida foram representados como vítimas da miséria, da felonia e da traição do comunismo iconoclasta que somente ganha felicidade quando "se sente empapado no sangue generoso e inocente das suas vítimas indefesas". ${ }^{14} \mathrm{O}$ discurso se encerra com a emulação do Exército para que o povo travasse uma luta sem trégua ao comunismo. O momento não era de simples homenagem aos militares mortos em 1935, mas o de intensa monstrualização do comunismo e dos comunistas do presente. A partir dessa romaria cívica, a sublevação militar de 1935, tornou-se um evento importante no calendário militar brasileiro, momento de ressignificação constante da memória, com a intenção de conquistar propósitos políticos. Assim, a monstrualização dos corpos de esquerda não dizia respeito ao fato em si, pois estes monstros foram, amiúde, deslocados do momento da convulsão monstruosa que os gerou para o momento presente, imediato de sua recepção - como uma ameaça constante que pode renascer a qualquer momento. ${ }^{15}$

\section{A SUBLEVAÇÃO MILITAR DE 35 COMO MONUMENTO DE PODER}

O anticomunismo brasileiro teve, no evento de 27 de novembro de 1935 , o seu monumento de poder, de conjugação de forças entre civis e militares; o comunismo havia passado da condição de mero espectro para o de medo real. A celebração em homenagem aos militares mortos ocorreu durante um longo período da história brasileira. ${ }^{16} \mathrm{O}$ evento tornou-se um momento privilegiado para o agenciamento anticomunista. Além de atuar como elemento catalisador das forças conservadoras, uma espécie de fonte reguladora da política nacional, o evento serviu para consolidar a visão conservadora e acelerar a modernização militar no interior da caserna. $\mathrm{O}$ militar brasileiro moderno agregou em seu universo profissional a doutrina anticomunista. Realmente, o anticomunismo militar atuou como combustível da máquina institucional garantindo a coesão militar nos quartéis e consolidando politicamente, para a sociedade civil, o Exército como o único baluarte contra o "perigo vermelho". Assim, o anticomunismo militar atuou como elemento fundamental na efetivação de práticas político-militares no sentido da despartidarização civil e da abertura na concretização da política do Exército. No plano interno a vigilância sobre os oficiais, por meio da $2^{\mathrm{a}}$ Seção do Estado-Maior, a partir do Estado Novo, estendeu uma linha territorial que aos poucos foi apartando os militares da política civil. ${ }^{17}$

O impacto imediato da procissão de 22 de setembro foi o da elaboração, um dia após o evento, pelo Legislativo brasileiro, do projeto n 662 de 1937. 
Nele o poder Legislativo decretava a construção, no cemitério de São João Batista, de um monumento em homenagem aos oficiais e soldados mortos por ocasião do levante de novembro de 1935; para isso foi organizado um concurso entre artistas brasileiros a fim de efetivar o projeto. ${ }^{18}$ A partir desse momento o evento de fato foi institucionalizado e o Exército assumiu o comando do ritual de rememoração dos militares mortos no cumprimento do dever. Na forma o roteiro do evento permaneceu basicamente o mesmo; a partir do projeto de lei organizou-se uma formatura de tropas militares junto ao monumento em memória aos mortos, recepção de autoridades civis e militares (fundamentalmente o Ministro da Guerra e o Presidente da República), canto do hino nacional, colocação de flores aos pés do monumento, discursos e leitura da ordem do dia dos chefes militares e a chamada nominal dos mortos ao som de salvas de canhão. ${ }^{19}$ Em todas as guarnições militares o evento também se fazia presente; havia toda uma preparação anterior, com palestras, missas e o encerramento com uma formatura solene. O evento aos mortos de 1935 representou o lócus decisivo para onde convergiam as forças conservadoras no sentido de garantir a coesão militar por meio de práticas de significados anticomunistas. Por certo, o anticomunismo militar responde a uma cultura política institucionalizada que, na ditadura do Estado Novo, ganhou cada vez mais possibilidade de formar uma identidade conservadora. A luta contra o "perigo vermelho" conduziu o Exército como ator político de caráter cada vez mais intervencionista. Para isso a banalização dos corpos dissidentes de esquerda passou a acompanhar as representações institucionais.

O evento de 1935 foi mitificado no Exército - basicamente a partir de 1937; as representações acerca dos fatos acorridos no levante político-militar são verdadeiramente sombrias. ${ }^{20} \mathrm{O}$ uso ordinário da expressão "Intentona Comunista", utilizado com intensidade a partir dos anos de 1960, identifica bem o contexto representacional anticomunista. Trata-se de um intento louco posto por monstros militares, seres tresloucados, deslocados da fé cristã e de qualquer moralidade. Contudo, estes monstros não amedrontavam apenas pela ausência dos qualificativos civilizacionais Ocidentais, mas essencialmente pela ameaça constante ao aparato cultural que garante ao indivíduo o exercício da liberdade. ${ }^{21}$

A mitificação do levante militar transferiu o evento do fato para a ficção, porém não nos parece produtivo, tal como numa investigação policial, apontar a "verdade" dos fatos. Há toda uma série de acusações anticomunistas, de assassinatos de forma torpe, que independentemente da ausência de documentação, marca o levante com efeitos de realidade. Na perspectiva da história, a recepção daquele momento de sublevação por parte dos atores políticos, se posta como elemento de compreensão do quadro institucional. Assim, a celeuma anticomunista no corpo institucional não foi imediatamente após a chamada novembrada de 1935; o ano de 1936, referente ao "perigo 
vermelho", à parte as manifestações singulares, não foi de grande alarme; a recepção do evento nos quartéis ecoou como mais uma sublevação tenentista. A apresentação do evento, por parte da instituição, como um movimento único de afronta à camaradagem militar - elementos que se voltaram contra os próprios companheiros - não confere com uma cultura de levantes militares de 1922, 1924 e 1930. Em suma, a ideia de traição aos camaradas militares atribuída aos oficiais de esquerda sublevados em 1935 não difere em essência do conjunto de revoltas militares da década anterior. ${ }^{22}$ Não obstante, houve todo um esforço institucional com o propósito de banalizar os corpos militares dissidentes do projeto conservador, essencialmente imputando a esses militares o assassinato dos companheiros que dormiam.

A ameaça monstruosa, além do evento de 1935, ganhou intensa realidade com a apresentação por parte do governo do Plano Cohen descoberto pelo Estado-Maior do Exército. Na verdade, tratava-se de um documento forjado dentro do próprio órgão militar pelo Capitão Olympio Mourão Filho, que descortinava a estratégia comunista de tomada do poder político nacional. Em 30 de setembro de 1937, poucos dias após a romaria cívica anticomunista, o plano ganhou publicidade pelos principais jornais do país. O efeito do Plano Cohen sobre a opinião pública era o de tornar mais realista e próxima a ameaça comunista ao país, legitimando a necessidade de um Estado de guerra. ${ }^{23}$ Para a instituição, a decretação do Estado de guerra ou mesmo a própria mentalidade de um estado de guerra permanente, possibilitava a concentração de força para a intensificação dos valores conservadores a partir do aumento do controle sobre o corpo militar. ${ }^{24}$

O ano de 1937 foi de articulação político-militar para que a instituição pudesse organizar-se em bloco, dirimindo as vozes dissidentes. $\mathrm{O}$ anticomunismo militar no ano seguinte passou a instituir-se de forma doutrinária. O Exército, a partir de então, deslocou todas as suas forças contra um inimigo fundamental: o comunismo. De tal forma que os documentos político-militares produzidos pela instituição, repetidas vezes, estavam permeados do "perigo vermelho". É importante acentuar que a ameaça comunista apresentava-se como uma força monstruosa, muito diferente do inimigo militar convencional. A ameaça perpassava todas as esferas públicas e privadas. $\mathrm{O}$ comunismo apresenta-se como elemento que degenera o corpo social, mas era no plano interno, no interior dos quartéis, que ele representava o maior perigo, pois atingia o alicerce de defesa da sociedade. A ameaça comunista nos discursos militares era de tom perene, uma ameaça sem fim, que mantinha a tropa em constante estado de vigilância Numa expressão militar: Em Guarda!

O perigo da esquerda revolucionária passa a ser o principal problema político nacional. Apresenta-se como uma força sub-reptícia sobre a qual toda a vigilância é necessária, pois subverte a ordem cultural Ocidental moderna. Não se trata exclusivamente do perigo em si, mas, como já foi dito, 
de transformação da ameaça comunista numa enorme caixa de pandora onde todos os problemas da ordem nacional eram depositados. $\mathrm{O}$ anticomunismo militar acentuava forças em tempos de crise política; o momento republicano que marca o uso institucional dos discursos anticomunistas foi meses antes da implantação do Estado Novo. Naquele momento o país vivia intensa crise política, fruto da intervenção estadual sobre a caserna - basicamente no Rio Grande do Sul, no governo de Flores da Cunha, momento de agitação política da oposição em geral ao governo Vargas. Em face disso, podemos perceber o aparecimento do "perigo vermelho" descrito pelo Ministro da Guerra, general Eurico Gaspar Dutra em junho de 1937, como o maior dos perigos que ameaça a nação brasileira e a instituição militar. Dado que o comunismo é o monstro político temível por ser organizado, pertinaz e nefasto por subverter toda a estrutura normativa construída em séculos de civilização; assim é: “[...] o mais digno de repulsa porque atinge os sagrados e invulneráveis dogmas da moral em que erigimos nossos santuários domésticos" ${ }^{25}$ Contudo, em termos práticos, o Estado Novo, além da perseguição ao comunismo nacional, teve um impacto maior sobre o regionalismo político brasileiro e graças a este impacto é que o Exército conseguiu deslocar o poder militar regional das forças públicas para o policiamento ostensivo, efetivando-se como poder militar nacional de fato.

De todas as frentes de defesa, em virtude da ameaça comunista, a preservação da caserna passou a assumir destaque. Como os quartéis apresentam-se isolados do mundo civil, o "perigo vermelho" só poderia expressar-se por meio de militares de esquerda. Efetivamente, o militar de esquerda era a expressão fundamental da ameaça comunista, na medida em que o sucesso da revolução passava pela sublevação na caserna. Logo, a ressignificação da memória de 1935 tinha como mote a criação institucional de um militar incompatibilizado com a ideologia marxista. Tal corpo político de esquerda era contrário à ordem militar, um corpo estranho que degenera a instituição. Nesse sentido, a vigilância é fundamental, pois as táticas exercidas por esses corpos são monstruosas. Assim, novamente de acordo com o Ministro da Guerra:

[...] É preciso não esquecer. Aqueles que um dia traíram a confiança de seus chefes e companheiros, voltarão amanhã a feri-los pelas costas, com maior perfídia e mais requintada indignidade. [...] Cumpre ao Exército não se deixar colher de surpresa. E cumpre aos chefes - que serão as primeiras vítimas da própria incúria - intensificar os meios de defesa que estão ao seu alcance. Impõe-se a vigilância constante sobre os elementos suspeitos; a caracterização precisa de suas atividades; a repressão imediata e impiedosa de qualquer ação de propaganda ou conquista; a denuncia desassombrada as autoridades e o afastamento dos que 
assim tenham se manifestado. E quando aos que tentarem perturbar a disciplina e demolir o prestigio da autoridade, cumpre sentir que a força se opõe a força, imediata, inexorável. É preciso fazer sentir que [...] o comunismo, sob qualquer aspecto ou modalidade, é incompatível com a condição militar $[\ldots] .{ }^{26}$

$\mathrm{O}$ rito anticomunista centrado na homenagem aos militares mortos em combate ao comunismo possibilitou ao Exército instituir o "perigo vermelho" como mecanismo geral de controle ordinário sobre os corpos militares. A fabricação de um inimigo monstruoso inculcou na tropa a mentalidade do estado de prontidão. A mentalidade militar conservadora monopolizou o anticomunismo militar. Assim, identificar-se contrário ao comunismo implicava a adesão ao pensamento conservador. $\mathrm{O}$ importante é que o anticomunismo militar, com a intensa banalização do inimigo político, pode nos apresentar toda uma maquinaria de poder por detrás das metáforas monstruosas, que assegurou a formação moderna da instituição militar.

A alocução do representante do Exército pronunciada em razão do evento de 1935 sintetiza a visão geral da instituição frente à "ameaça vermelha". Em 1938 o major Afonso de Carvalho descreve o comunismo como o inimigo invisível - é a ubiquidade do monstro comunista; ele pode ocupar qualquer espaço, na maioria das vezes não se apresenta abertamente. Assim, em seu discurso ele diz: "Meus camaradas! Longe vai o tempo em que mais simples, muito mais simples, se tornava a missão do soldado. Sabia-se, pelo menos, onde estava o inimigo. Era partir para frente e aí esperar que o mais forte impusesse a sua vontade. [...] Hoje, mais difícil se tornou a missão do militar. O inimigo está em toda a parte [...]". ${ }^{27}$ Em substância, essa ubiquidade é o que vai alimentar o combate ao comunismo e, fundamentalmente, criar um mote disciplinar anticomunista na caserna - conduzindo a modernização militar sob a égide do profissionalismo que, amiúde, confundia-se com a ojeriza ao monstro político comunista; em outras palavras: ser profissional e anticomunista passaram a ser questões de mesma ordem.

Tal relação, estrategicamente posta, facilitou o isolamento dos corpos desviantes no interior da caserna. Estes foram banalizados, de acordo com as personalidades políticas individuais; se declaradamente de esquerda, o militar era logo monstrualizado; se contrário aos meios militares de combate ou apresentação do "perigo vermelho" era percebido como um militar inconscientemente envolvido nas teias do comunismo. Do ponto de vista profissional, os corpos dissidentes, no geral, foram apresentados como péssimos oficiais - despossuídos de cultura militar, péssimos chefes e extremamente ligados à cultura paisana.

Com referência ao discurso do major Afonso de Carvalho, podemos observar, ainda, que há nele a busca da universalização do "perigo vermelho"; os comunistas dividem-se em três grandes classes: 
Conscientes: são os envenenados, os que vencidos pela ideologia, subjugados pela doutrina ou filiados "ao sindicato dos desesperados", com inveja e ambição, cultivam a vingança da miséria, e passam a constituir a legião sombria dos voluptuosos da morte e da destruição.

Inconscientes: são os que fazem, sem querer, o jogo dos comunistas e, no livro, na tribuna, na revista, no jornal, na vida cotidiana muitas vezes presos a negócios inconfessáveis, não trepidam em descer das suas responsabilidades para mancomunarem ou se solidarizarem com os que fazem obra de comunismo - de dissociação e de dissolvência - e se tornam os joguetes desprezíveis na mão dos espíritos que os vencem em inteligência, diabolismo e perversidade. Subconscientes: os que têm, lá no fundo do coração e do espírito, ideias comunistas, ainda disfarçadas ou em embrião, mas que afloram, à sorrelfa, indiscretamente, em seus trabalhos, publicações de leitura e opiniões. ${ }^{28}$

A estrutura pan-óptica, posta no texto acima, assegura a ameaçadora presença do comunismo no corpo social de tal forma que qualquer posição política progressista poderia ser classificada como comunista. O comunista é, efetivamente, o monstro sem Pátria, elemento sobre o qual tudo é possível e tudo é permitido. Enfim, independentemente do nível de comprometimento com a causa, são todos apresentados como monstros políticos - que temos que evitar e combater. Este monstro é corpóreo e incorpóreo, manifesta-se por todos os espaços da consciência, sua grande ameaça é a propensão de mudar de um nível para outro. ${ }^{29}$ Por essa forma, consoante o major Afonso de Carvalho, independentemente das classes de consciência comunista, todos eles apresentam-se como traidores da Pátria; sendo assim nenhum vínculo com eles é possível; indubitavelmente, são monstros políticos, corpos que devem ser sujeitados - o que justifica: "todas as medidas de prevenção e toda a brutalidade da repressão". ${ }^{30}$

A homenagem, em 1938, aos militares mortos na "Revolução Comunista" ganhou forma institucional; o dia 27 de novembro passou a ser de fundamental importância no calendário militar - somando-se ao dia 25 de agosto (dia do soldado). O representante do Exército (o agora general Valetim Benício da Silva, o mesmo que logo após o levante armado de 1935 proferiu discurso de tom anticomunista num contexto extremamente favorável de vigilância absoluta sobre qualquer corpo dissidente), pronunciou discurso apresentando o anticomunismo institucional. Assim, em suas primeiras palavras dirige-se aos mortos: "Aqui estamos trazendo-vos a palavra do Exército que é a vossa própria Pátria". ${ }^{31}$ A extensão da instituição militar como força nacional, como representação da nação, na defesa à ameaça comunista, foi preponderante na formação de uma mentalidade militar intervencionista. A banalização do "perigo 
vermelho", no interior dos quartéis, tornou possível nos momentos de crise a coesão militar, para isso a produção de imagens referentes às práticas produzidas na "Revolução Comunista" foram de fundamental relevância. Destarte, a banalização dos corpos de esquerda teve um papel singular para a unidade da tropa. Assim, a locução do representante do Exército no evento de 27 de novembro acentuava: "[...] o comunismo explodiu na sua cegueira infrene. Alta noite, o punhal assassino, a amizade fementida, a arma de defesa transformada em baioneta agressiva, juramentos e compromissos cinicamente renunciados, despertou a cidade de seu sono reparador e tranquilo". ${ }^{32}$ A amoralidade do monstro comunista, na imagem do militar de esquerda, foi constantemente elaborada por meio dos discursos político-militares, objetivando a absoluta incompatibilidade entre a profissão militar e o comunismo.

\section{EXPELINDO DO CORPO INSTITUCIONAL O ABJETO COMUNISTA}

Em 1939 Eurico Gaspar Dutra, Ministro da Guerra, e Góes Monteiro, Chefe do Estado-Maior do Exército, introduziram profundas mudanças na estrutura da instituição militar. A mais impactante foi a garantia de estabilidade no serviço militar apenas para os oficiais; assim, de acordo com Werneck Sodré: "Éramos forçados a dar baixa compulsória, a velhos soldados [...]". ${ }^{33}$ Os sargentos após dez anos de serviço passavam por rigorosos reengajamentos, muitos dos quais não satisfaziam as exigências, dentre elas as dos cursos de acesso, sendo excluídos da corporação. ${ }^{34}$ Foi uma medida de conteúdo políticomilitar, para aquele momento, a fim de concentrar os esforços de unidade da tropa nos oficiais; de forma que, a partir de então, a coesão militar passou a representar o propósito necessário à estruturação do Exército. Em relatório do Ministro da Guerra ao Presidente Getúlio Vargas, podemos perceber a vontade institucional:

Sendo o Exército um grupamento de homens livres, conscientemente reunidos sob o império da necessidade primordial da defesa nacional, homens que vivem debaixo da direção de ideias semelhantes e de idênticos intuitos, não pode e não deve haver a mínima discrepância no modo de agir, na maneira de pensar e no modo de sentir de cada um dos membros componentes da força armada nacional. A lei do conformismo social e da eliminação dos não conformistas forma a base moral da estrutura disciplinar do Exército e justifica a severa repressão dos elementos dissidentes ou rebelados. ${ }^{35}$ 
De modo real, a ameaça comunista foi o que assegurou o tom conservador da estruturação institucional em 1939; com referência ao dia 27 de novembro de 1935, o discurso do general Dutra corrobora o caráter identitário anticomunista forjado pelos militares conservadores - caráter esse que conduziu a modernização da instituição. As palavras do general acentuaram a tendência perversa e covarde das ações comunistas; assim: “[...] usando de todos os recursos da mistificação, da surpresa e da violência, pretendeu irradiar a sua ação agressiva e corruptora, com a pretensão de dispor das armas brasileiras, como se o Exército pudesse compartilhar de tamanho crime [...]" ${ }^{36} \mathrm{O}$ discurso também enfatiza a defesa da Pátria e da família, pois o monstro comunista ameaça a ordem social e a moral cristã da família burguesa. Com as seguintes palavras o general finaliza seu discurso: "[...] continuemos vigilantes, jamais cometendo o erro de desprezar a força do inimigo, por mais fraco que possa parecer, e sempre atento na defesa do patrimônio moral da família brasileira e da integridade da Pátria [...]". ${ }^{37}$ No mesmo evento, representando o Exército, o general Góes Monteiro insistiu na importância da instituição militar como núcleo fundamental da coesão nacional e da ordem pública - daí a posição do Exército como ponto sensível às ações comunistas. A imagem dos corpos que ameaçaram a ordem, no discurso do general, estava carregada de arquétipos anticomunistas. Assim, conforme as palavras de Góes Monteiro:

Vimos um punhado de desvairados, instruídos por agentes estrangeiros, sujeitos a uma paralisia alucinada das funções superiores da humanidade, tangidos por uma libertação macabra dos instintos mais baixos, inédita na história de nossos desequilíbrios sociais - vimo-los entre delírios inauditos, tentar impor à Nação um regime contrário a todos os valores de nessa tradição. ${ }^{38}$

Decisivamente, o comunismo é apresentado como abjeto ${ }^{39}$, conduzido pelo monstro político de esquerda - aquele ser monstruoso que rompe o pacto social burguês e nos devolve ao estado de natureza hobbesiano. Góes Monteiro elabora a imagem desses corpos como aqueles que resgatam forças primitivas com cores modernas. Posto que de acordo com ele: “[...] Esses monstros realizam a sobrevivência de enterrados atavismos, apetrechados de todas as conquistas do progresso". ${ }^{40}$ Efetivamente, trata-se de monstros abjetos que corrompem a ordem moderna e inviabilizam o progresso; são os elementos que devem ser alijados do interior da caserna e do corpo social, pois ameaçam impor o caos; destarte, só um estado hobbesiano (forte) moderno poderia salvaguardar a nação desta ameaça.

Os discursos referentes à memória de 1935 - independentemente da ameaça nem sempre real do "perigo vermelho", fundamentalmente com o esmagamento político do comunismo no Estado Novo e mesmo durante 
o Regime Militar - ainda reforçavam o perigo e a ubiquidade da presença comunista. Contudo, o anticomunismo militar como expressão política não assumiu a mesma forma o tempo todo; por exemplo, o momento de transformação da estrutura do Exército em força nacional foi marcado pela fase do anticomunismo doutrinário. Nela o anticomunismo foi, decisivamente, a ideologia disciplinadora da ordem militar republicana moderna. Porém, é fundamental compreender que as Forças Armadas, muito mais do que inventar um tipo específico de anticomunismo, apropriaram-se do medo das elites brasileiras do "monstro popular" - como empecilho à modernidade capitalista.

Decerto, travou-se uma dura guerra contra o comunismo; o alvo principal foi localizado na figura dos militares envolvidos no movimento político-militar de 1935. A banalização dos militares de esquerda visava a isolálos do corpo da tropa, rompendo os laços de camaradagem com os companheiros militares, além de servir como elemento de unidade institucional - para isso toda uma cultura foi inventada a fim de desqualificá-los enquanto movimento de tradição tenentista. ${ }^{41}$ Destarte, a banalização dos corpos de esquerda foi articulada a partir de dois grupos de imagens: o primeiro grupo centrado na vilania monstruosa de suas ações e o segundo, no poder sobre-humano do comunismo. Em síntese, a imagem construída apontava para a monstrualização dos corpos, monstrualizando a própria memória do evento. Ademais, a imagem da instituição militar como a de ponto sensível à ação comunista, posto que era a única força capaz de defender o país contra o "perigo vermelho", foi, amiúde, apresentada por meio do anticomunismo militar. Para o general Firmo Freire do Nascimento:

O maior risco [...] está na infiltração das classes armadas, esteio da nacionalidade. Para o bolchevismo, a ação revolucionária deve ser organizada principalmente no seio delas. Buscando apoderar-se da alma do soldado, conta estancar nas fontes mais puras o sentimento da honra militar, suplantando a disciplina - alma da ordem. ${ }^{42}$

Os misteriosos poderes atribuídos aos comunistas foram suficientes para que fosse produzido o estereótipo de que contra os comunistas tudo era possível e permitido, pois moralmente eles estavam abaixo da condição humana, contudo portavam forças políticas sobre-humanas. Segundo Werneck Sodré: "tratavase, não de gente, de criaturas humanas, mas de animais perigosos, contra os quais todos os processos eram lícitos". ${ }^{43}$ Em face disso, a ressignificação do evento marcando a metamorfose do monstro político, traduz a representação do movimento político-militar de 1935 como estratégia política que gerou práticas disciplinares que bastavam por si mesmas. Eis, novamente, as palavras do Ministro da Guerra general Eurico Gaspar Dutra: 
Malogrado o primeiro ímpeto, o inimigo da ordem não esmorece, não desanima, não dorme. Apenas muda de tática. Disfarça-se, finge-se debilitado, esconde melhor as energias que se articulam. Infiltra-se em todas as fileiras, procura instalar-se ao nosso lado, simula comungar em nossos ideais, empenha-se em conquistar nossa simpatia e nossa confiança. ${ }^{44}$

Em suma, o comunismo foi o abjeto que desestabilizou a identidade moderna, a ordem burguesa, pois, em essência, negava a única norma possível. Naturalmente, a utopia materialista marxista pôs em cheque o "eu" moderno do "livre mercado" e da "livre fé". É o que encontramos no pronunciamento do general Salvador César Obino: "sem os freios que só um elevado idealismo pode criar e manter, os homens, como as nações, tendem para a violência sistematizada; é o predomínio da lei da selva. Extirpar do homem a força criadora da fé é reduzi-lo a simples condição de animalidade". ${ }^{45}$ Numa perspectiva, tal pronunciamento adquire maior compreensibilidade teórica a partir da tese de Samuel Huntington, de que as instituições militares são conservadoras em sua essência, o que aproxima os militares de Hobbes, da guerra de todos contra todos e da negatividade da natureza humana - o homem é o lobo do homem. ${ }^{46} \mathrm{O}$ comunismo conduziria o corpo social à condição de lobos. Na realidade, o medo moderno do estado de natureza hobbesiano estava na mesma ordem do medo geral do comunismo político por parte dos militares conservadores. Entretanto, o medo não explica todos os efeitos das imagens anticomunistas produzidas pelos militares, pois quando analisamos o papel da monstrualização da esquerda política, no interior da instituição militar, podemos vislumbrar o impacto do anticomunismo militar como força de estruturação do Exército - principalmente no Estado Novo. É importante compreender que os monstros modernos se apresentam como metáforas de um processo político que traduz práticas de controle, sujeição dos corpos monstrualizados e, até mesmo, seu extermínio. O que corporifica o momento cultural de uma época, de um sentimento de exclusão e de um espaço que se busca purificar. ${ }^{47} \mathrm{Em}$ face disso, compreendê-los como corpo anormal não é tudo, é preciso resgatar a historicidade do processo de monstrualização, de banalização moderna para, enfim, mobilizar os documentos como monumentos de poder.

\section{CONSIDERAÇÕES FINAIS}

A luta contra o comunismo se colocava como uma cruzada democrática e cristã com a intenção de esmagar da política nacional os corpos de esquerda - a estratégia era a de banalização desses corpos. Nada de novo. Havia uma espécie de ubiquidade da presença comunista, isto é, os comunistas poderiam 
ser encontrados em todas as instituições do país, defendendo concepções comunistas ou, às vezes, paradoxalmente, contrárias aos princípios comunistas, como a defesa da liberdade e da democracia, uma mera aporia tática. Deste modo, os homens e as mulheres de bem deveriam permanecer com os olhos bem abertos, posto que a doutrinação comunista assumia um tom subliminar, transformando qualquer pessoa em "inocente útil". No editorial da revista "A Defesa nacional" de 1960 é possível encontrar as seguintes palavras: "você está a par de como o comunista oculto, ocupando um ponto saliente no governo, no jornalismo, nas sociedades trabalhistas, na igreja ou nas escolas, pode inocular em seu espírito o veneno suficiente para tornar você elemento de propaganda, ou seja, um inocente útil". ${ }^{48}$ Efetivamente, o tom monstruoso dado aos comunistas deve ser percebido como um processo político a fim de banalizar o "outro" a partir da invenção de um corpo com poder de sedução capaz de corromper a ordem cristã, pois não se trata de um mero discurso fantasioso de poder que se limita a si mesmo, mas de uma estratégia que busca a normalização de uma posição de poder, de modo que foi preciso monstrualizar o outro para torná-lo corpo submisso.

Em substância, a partir do Estado Novo o anticomunismo militar passou efetivamente à fase doutrinária, momento em que se utilizou de mecanismo de agenciamento institucional, buscando expressar a absoluta incompatibilidade do comunismo com a condição militar. $\mathrm{O}$ anticomunismo do Exército apresentouse como uma máquina de coesão institucional, que classificava e deslocava todo o corpo desviante. O evento militar de 1935 foi, sem dúvida, a matriz ideológica do anticomunismo militar; os militares conservadores transformaram o evento em monumento. Efetivamente, os textos que relembram este momento histórico não são simples documentos que traduzem a ojeriza militar aos comunistas, mas representam monumentos de ação político-militar que possibilitaram erigir práticas políticas que sustentaram as transformações no interior da instituição. Esses documentos apresentam-se como estratégias de controle político na forma de verdadeiros panótipos modernos que enquadram a todos, de tal forma que deles não escapava ninguém. Como, segundo Michel Foucault, não há exercício de poder sem uma economia dos discursos que reivindica a verdade, o anticomunismo militar foi, por certo, uma economia política dos discursos a respeito da verdade institucional, por meio do qual funcionavam as relações de poder ${ }^{49}$ Efetivamente, foi esta economia política que garantiu uma estrutura institucional capaz de apresentar um pensamento dominante que resultou numa identidade específica de cunho profissional e anticomunista. 


\section{NOTAS}

${ }^{1}$ HOBSBAWM, Eric. Era dos Extremos. São Paulo: Companhia das Letras, 1995. p. 229.

${ }^{2}$ FOUCAULT, Michel. Os Anormais. São Paulo: Martins Fontes, 2001. p. 118.

${ }^{3}$ MOTTA, Rodrigo Patto Sá. Em guarda contra o perigo vermelho. São Paulo: Perspectiva: FAPESP, 2002. p.3.

${ }^{4}$ ESTADO-MAIOR DO EXÉRCITO. Em Guarda! (Contra o Comunismo). 1938. p. 214.

${ }^{5}$ CARVALHO, Fernando de. Lembrai-vos de 35! Rio de Janeiro: Biblioteca do Exército, 1981. p. 164.

${ }^{6}$ COHEN, Jeffrey Jerome. A cultura dos monstros: sete teses. Belo Horizonte: Autêntica, 2000. p. 33 .

${ }^{7}$ FOUCAULT, op. cit., p. 115.

8 GEERTZ, Clifford. A interpretação das culturas. Rio de Janeiro: LTC, 1989. p. 15.

${ }^{9}$ COHEN, op. cit., p. 26-27.

${ }^{10}$ ESTADO-MAIOR DO EXÉRCITO, op. cit., p. 202-202.

${ }^{11}$ Ibidem, p. 205.

${ }^{12}$ Ibidem, p. 211.

${ }^{13}$ Ibidem, p. 214.

${ }^{14}$ Ibidem, p. 214.

${ }^{15}$ COHEN, op. cit., p. 27.

${ }^{16}$ MOTTA, op. cit., p. 83.

${ }^{17}$ FERREIRA, Roberto. Organização e poder: análise do discurso anticomunista do Exército brasileiro. São Paulo: Annablume, 2005. p. 40.

${ }^{18}$ ESTADO-MAIOR DO EXÉRCITO, op. cit., p. 241.

${ }^{19}$ CASTRO, Celso. A invenção do Exército brasileiro. Rio de Janeiro: Zahar, 2002. p. 52.

${ }^{20}$ MOTTA, op. cit., p. 76.

${ }^{21}$ COHEN, op. cit., p. 40.

${ }^{22}$ MOTTA, op. cit., p. 78.

${ }^{23}$ SILVA, Hélio. A ameaça vermelha: o Plano Cohen. Porto Alegre: L\&PM editora, 1980. p. 9.

${ }^{24}$ FERREIRA, op. cit., p. 93.

${ }^{25}$ ESTADO-MAIOR DO EXÉRCITO, op. cit., p. 37.

${ }^{26}$ Ibidem, p. 38-39.

${ }^{27}$ CARVALHO, op. cit., p. 180.

${ }^{28}$ Ibidem, p. 181.

${ }^{29}$ COHEN, op. cit., p. 28.

${ }^{30}$ Ibidem, p. 182. 
${ }^{31}$ Ibidem, p. 185.

${ }^{32}$ Ibidem, p. 186.

${ }^{33}$ SODRÉ, Nelson Werneck. Do Tenentismo ao Estado Novo. Petrópolis: Vozes, 1986. p. 198.

${ }^{34}$ Ibidem, p. 199.

${ }^{35}$ CENTER FOR RESEARCH LIBRARIES. Ministerial Reports Guerra, 1827-1939. p. 22. Disponível em: <http://brazil.crl.edu/bsd/bsd/u2341/000023.html>. Acesso em: 17 fev. 2013.

${ }^{36}$ Boletim do Exército, n. 53 de 1939.

${ }^{37}$ Ibidem.

${ }^{38}$ CARVALHO, op. cit., p. 199.

${ }^{39} \mathrm{O}$ abjeto, conceito elaborado por Julia Kristeva, é tudo o que ameaça a norma e a ordem ideológica moderna, enfim o conforto da sensação de identidade. É aquilo que sai do corpo provocando atração e repulsão - no caso específico da instituição militar, pensamos a caserna como um corpo orgânico e os militares de esquerda como um abjeto, uma secreção rejeitada com repulsão, que sai do próprio corpo militar ou da sociedade política. Daí a necessidade de expelir esse abjeto como corpo físico e como documento. Ou seja, o militar conservador encontra conforto identitário quando se expeli completamente esse abjeto do corpo. SILVA, Tomaz Tadeu. Teoria cultural e educação: um vocabulário crítico. Belo Horizonte: Autêntica, 2000. p. 13.

${ }^{40}$ CARVALHO, op. cit., p. 200.

${ }^{41}$ SODRÉ, Nelson Werneck. A história militar do Brasil. Rio de Janeiro: Civilização Brasileira, 1968. p. 258.

${ }^{42}$ CARVALHO, op. cit., p. 210.

${ }^{43}$ SODRÉ, 1968, op. cit., p. 259.

${ }^{44}$ CARVALHO, op. cit., p. 221.

${ }^{45}$ Ibidem, p. 230.

${ }^{46}$ HUNTINGTON, Samuel. O soldado e o Estado: teoria e política das relações entre civis e militares. Rio de Janeiro: Biblioteca do Exército, 1996. p. 81.

${ }^{47}$ COHEN, op. cit., p. 33.

${ }^{48}$ Editorial publicado na revista A Defesa Nacional, n. 554, set. 1960.

${ }^{49}$ FOUCAULT, Michel. Em defesa da sociedade. São Paulo: Martins Fontes, 1999. p. 28.

Artigo recebido em janeiro de 2013. Aceito em junho de 2013. 